\title{
An evaluation of production efficiencies among lactating Holstein-Friesian, Jersey, and Jersey $\times$ Holstein-Friesian cows at pasture
}

\author{
R. Prendiville, ${ }^{\dagger} \dagger$ K. M. Pierce, $†$ and F. Buckley ${ }^{* 1}$ \\ ${ }^{*}$ Teagasc, Moorepark Dairy Production Research Centre, Fermoy, Co. Cork, Ireland \\ †School of Agriculture, Food Science \& Veterinary Medicine, UCD, Belfield, Dublin 4, Ireland
}

\begin{abstract}
The objectives of this study were 1) to investigate production and energetic efficiencies among lactating dairy Holstein-Friesian (HF), Jersey (J), and Jersey $\times$ Holstein-Friesian $\left(F_{1}\right)$ cows over a total lactation at pasture and 2) to measure the associations among efficiency variables and performance traits. Data from 110 cows were available $\left(37 \mathrm{HF}, 36 \mathrm{~J}\right.$, and $\left.37 \mathrm{~F}_{1}\right)$. Breed groups were not balanced for parity; $16 \mathrm{HF}, 10 \mathrm{~J}$, and 9 $\mathrm{F}_{1}$ were in parity 1 , whereas the remainder were in parity 2. Milk production, body weight (BW), body condition score (BCS), and estimates of dry matter intake (DMI) corresponding to 51, 108, 149, 198, and $233 \mathrm{~d}$ in milk were available. Breed group had a significant effect on all the production parameters investigated: milk yield, solids-corrected milk (SCM), milk fat, protein and lactose concentrations, and milk solids (MLKS; fat + protein yield). Daily MLKS yield was similar for HF and $\mathrm{J}(1.33$ and $1.28 \mathrm{~kg} / \mathrm{d}$, respectively). There was a tendency for $F_{1}(1.41 \mathrm{~kg} / \mathrm{d})$ to produce more MLKS compared with HF. The HF breed had higher BW throughout the study compared with $\mathrm{F}_{1}$ and J. Mean BCS was higher for $\mathrm{F}_{1}$ (3.00) and $\mathrm{J}$ (2.93) compared with HF (2.76). Mean DMI was similar with HF (16.9 $\mathrm{kg})$ and $\mathrm{F}_{1}(16.2 \mathrm{~kg})$ and was lowest with $\mathrm{J}(14.7 \mathrm{~kg})$. Breed group had a significant effect on all the efficiency parameters investigated: total DMI per $100 \mathrm{~kg}$ of BW, SCM per $100 \mathrm{~kg}$ of BW, MLKS per $100 \mathrm{~kg}$ of BW, and MLKS per total DMI, which tended to be highest for J. Production efficiency based on net energy intake per MLKS was most favorable for $\mathrm{F}_{1}$ and $\mathrm{J}$ compared with HF $[12.5,13.0$, and $14.1 \mathrm{UFL}$, respectively, where 1 UFL is defined as the net energy content of $1 \mathrm{~kg}$ of standard barley for milk production (O'Mara, 2000)]. Significant estimates of hybrid vigor were evidenced for milk yield, milk lactose content, SCM, MLKS, net energy for lactation, BW, BCS, and net energy intake per MLKS. The correlations examined indicated that
\end{abstract}

Received April 14, 2009

Accepted August 4, 2009

${ }^{1}$ Corresponding author: Frank.buckley@teagasc.ie production efficiency was positively associated with MLKS yield.

Key words: Jersey, feed efficiency, crossbreeding, hybrid vigor

\section{INTRODUCTION}

Efficient conversion of feed input to product is critical to economic profitability of the dairy production business. Total feed costs account for approximately $80 \%$ of the total variable costs associated with milk production (Shalloo et al., 2004). Therefore, in theory, overall farm profit could be increased by improving cow efficiency with regard to the conversion of energy intake to milk production. Breeding objectives globally have evolved of late, with increased emphasis being placed on survival and functional (health) traits as well as on production performance (Miglior et al., 2005). Selection in dairy cattle, for the most part, has not incorporated feed intake or feed efficiency as selection traits per se, predominantly because of a lack of information on nutrient intake and utilization by individual cows (Ngwerume and Mao, 1992).

Production efficiency can be defined in various ways. Gross efficiency, a commonly used measure of efficiency for lactating dairy cows, is usually expressed as the ratio of milk yield or milk solids (MLKS; $\mathrm{kg}$ of fat and protein) per unit of feed intake (Lopez-Villalobos et al., 2008). Other studies use net efficiency, which represents, in some form, the ratio of milk energy to total energy intake, having accounted for the energy required for maintenance, BW change, and other energy uses (Schwager-Suter et al., 2001). Alternatively, residual feed intake (RFI), first proposed by Koch et al. (1963), is the unexplained (remaining) energy from the total net energy intake (NEI), having accounted for all net energy uses. The RFI value denotes the difference in the utilization of energy by the cow relative to the population or group mean. Usually, it is represented as the difference between actual feed intake and that predicted based on the requirements for maintenance, milk production, BW, BW change, and, where appropriate, stage of pregnancy, with a more negative value signifying greater efficiency. 
Differences in DMI and varying measures of feed conversion efficiency (FCE) between dairy cows of various pure breeds have been reported previously (Oldenbroek, 1988; Mackle et al., 1996; Rastani et al., 2001). Although many studies deal with comparisons between Holsteins $(\mathbf{H})$ and Jerseys $(\mathbf{J})$, the majority date back to the late 1980s and early 1990s (Grainger and Goddard, 2004) and few include the $\mathrm{J} \times$ HolsteinFriesian $\left(\mathbf{F}_{1}\right)$. The review by Grainger and Goddard (2004) reported that in 8 out of 11 studies, pure J cows consumed more DM per $100 \mathrm{~kg}$ of BW compared with $\mathrm{H}$ or Friesian $(\mathbf{F})$ cows. These studies represented evaluations undertaken from 14 to 300 DIM and varied from farm system comparisons over 3 yr to short-term calorimetry experiments. Furthermore, studies varied from indoor experiments, where cows were offered a TMR diet, to pasture-based environments. The mean result indicated that $\mathrm{J}$ cows consumed $5.1 \%$ more than $\mathrm{H}$ and $\mathrm{F}$ cows when expressed as DM per kilogram of metabolic BW. This implies that J cows have a high intake capacity per unit of BW.

Concern for decreased additive genetic merit for fertility and health within the $\mathrm{H}$ breed has resulted in renewed global interest in crossbreeding (Hansen, 2006; Walsh et al., 2007). In Ireland, interest in crossbreeding with $\mathrm{J}$ is fueled by inadequate reproductive performance within Holstein-Friesian (HF) herds, a need to maximize MLKS production per hectare, and, more recently, the introduction by most milk processors of a multicomponent index system of milk payment (Shalloo, 2007). A 5-yr study evaluating the performance of $\mathrm{HF}, \mathrm{J}$, and $\mathrm{F}_{1}$ under Irish grass-based production conditions was established by Teagasc Moorepark at the Ballydague research farm in 2006. This study provided a unique opportunity to investigate the reputed feed efficiency differences between the HF and J and, importantly, their cross.

The difficulty in measuring feed intake, especially from pasture-based environments, might imply that efficiency measures, particularly RFI, may not be economically viable in dairy breeding schemes (McNaughton and Pryce, 2008). Efficiency measurements taken at one point in time, when considered over the total lactation or total lifetime, may not hold true. Because estimating feed efficiency is a costly process, it is of considerable interest to elucidate whether relationships exist between feed efficiency and traits that can be easily measured (or that are already included in selection goals), such as production potential. The objectives of this study were therefore 1) to estimate production and energetic efficiencies among lactating dairy $\mathrm{HF}$, J, and $\mathrm{F}_{1}$ cows over a total lactation at pasture and 2) to measure the associations among the efficiency variables and performance traits that might elucidate relationships between efficiency and more easily measured traits, such as milk production.

\section{MATERIALS AND METHODS}

Data from 110 cows were available: $37 \mathrm{HF}, 36 \mathrm{~J}$, and $37 \mathrm{~F}_{1}$. Breed groups were not balanced for parity; $16 \mathrm{HF}, 10 \mathrm{~J}$, and $9 \mathrm{~F}_{1}$ were in parity 1 , whereas the remainder were in parity 2. Mean calving date for all cows was February 18. A total of 13, 13, and 6 sires were represented in the $\mathrm{HF}, \mathrm{J}$, and $\mathrm{F}_{1}$, respectively. All $\mathrm{F}_{1}$ animals were sired by $\mathrm{J}$ bulls and out of $\mathrm{HF}$ cows. The HF sires were of North American HF (84\%) and New Zealand $(16 \%)$ origin. The proportion of HF in the trial HF cows was $89 \%$ (SD 11.3). The mean PTA (across breed) and standard deviations (in parentheses) for the HF sires used were as follows: $+179 \mathrm{~kg}$ (110.3), $+10 \mathrm{~kg}(4.7),+9 \mathrm{~kg}(3.1),+0.06 \%(0.11)$, and $+0.06 \%$ (0.05) for milk yield, fat yield, protein yield, and fat and protein concentration, respectively (http://www. icbf.com; accessed April 2009). Comparable PTA for the $\mathrm{J}$ sires (SD in parentheses) were as follows: -364 $\mathrm{kg}(164),+12 \mathrm{~kg}(8),-1 \mathrm{~kg}(7),+0.59 \%(0.20)$, and $+0.25 \%(0.08)$. The J sires were of New Zealand (64\%) and Danish (36\%) origin. Of the $13 \mathrm{~J}$ sires, 4 were represented in both the $\mathrm{J}$ and $\mathrm{F}_{1}$ cows. These 4 sires accounted for 21 and 31 of the $\mathrm{J}$ and $\mathrm{F}_{1}$ cows, respectively. All sires were representative of the sires commonly used in Ireland.

\section{Feeding System and Cow Management}

The experimental region was a permanent grassland site consisting of a sward with almost $100 \%$ perennial ryegrass (Lolium perenne L.). The soil type on the farm was free-draining acid brown earth of sandy loam to loam texture. Cows were turned out to grass in early February until mid-November and were housed during the winter months. A 10 -wk dry period was given to first-lactation animals, whereas an 8-wk dry period was deemed sufficient for multiparous animals. During the winter, all animals were offered grass silage ad libitum and dry cow minerals at a rate of $100 \mathrm{~g} / \mathrm{cow}$ per day. During the risk periods (February to May and September to November) calcined magnesite (Nutribio, Cork, Ireland) was dusted on the paddocks at a rate of $60 \mathrm{~g} /$ cow per day to prevent magnesium deficiency. Cows grazed as a single herd under a rotational grazing system, as described by Dillon et al. (1995). The cows were allocated fresh pasture every $24 \mathrm{~h}$. Concentrate supplementation over the lactation totaled $240 \mathrm{~kg}$ of $\mathrm{DM} /$ cow, and it was offered as a supplement in early lactation until pasture growth met demand (Kennedy et al., 2007). All concentrate supplementation was offered 
on a flat-rate basis in individual stalls twice daily during milking. Cows were milked twice daily at 0700 and $1545 \mathrm{~h}$, with concentrates offered in 2 equal feeds on a flat-rate basis during each milking. The composition of the concentrate was citrus pulp, $300 \mathrm{~g} / \mathrm{kg}$; barley, 237 $\mathrm{g} / \mathrm{kg}$; corn (Zea mays) gluten feed, $213 \mathrm{~g} / \mathrm{kg}$; soybean meal, $140 \mathrm{~g} / \mathrm{kg}$; vegetable fat, $30 \mathrm{~g} / \mathrm{kg}$; caned molasses, $50 \mathrm{~g} / \mathrm{kg}$; and minerals, $30 \mathrm{~g} / \mathrm{kg}$.

\section{Animal Measurements}

Throughout the year, milk yield was recorded daily using electronic milk meters (Dairymaster, Causeway, Co. Kerry, Ireland), with milk constituents determined from successive morning and evening samples of milk taken weekly, and was analyzed using a MilkoScan 203 instrument (DK-3400, Foss Electric, Hillerød, Denmark). Individual DMI measurements were carried out using the $n$-alkane technique (Mayes et al., 1986) as modified by Dillon (1993). The procedure was carried out as described by Berry et al. (2007). Body weight was recorded weekly using a calibrated weighing scale (Dairymaster, Causeway, Co. Kerry, Ireland) and twice weekly during the measurement periods to minimize the effect of variations in gut fill. Daily BW change during the measurement periods was calculated as the difference between the BW during the week of measurement plus the previous 2 wk and the BW during the week of measurement plus the following $2 \mathrm{wk}$, divided by 14 (Buckley et al., 2000). Body condition score was measured approximately every 3 to 4 wk throughout the study (always within 1 wk of intake measurement), by a single evaluator, on a scale of 1 to 5 (with 1 being extremely thin and 5 being extremely fat) with increments of 0.25 , similar to the scoring described by Lowman et al. (1976).

\section{Sward Measurements}

Throughout the grazing season, 40 pre- and postgrazing sward heights were recorded on all paddocks with a rising plate meter (Urban and Caudal, 1990). Pregrazing herbage yields $(>4 \mathrm{~cm})$ were determined for each paddock based on 5 quadrats $(0.25 \times 0.25 \mathrm{~m})$ of grass cut using an electronic shears, as described by O'Donovan et al. (2002). The herbage from each cut was collected and weighed, and a subsample (approximately $100 \mathrm{~g}$ ) was dried overnight at $60^{\circ} \mathrm{C}$ for DM determination. The remainder of the sample was freeze-dried and used for chemical analysis. Composites of the samples were bulked for each week of the experiment. During the intake periods, herbage samples representing the grass grazed by the animals were manually collected on d 6 to 11 to facilitate analysis by the $n$-alkane technique (Mayes et al., 1986).
Grass budgeting was carried out weekly to monitor grass growth. Pasture quality was maintained by removing surplus grass as baled silage. Average pregrazing yields $(>4 \mathrm{~cm})$ were $1,377 \mathrm{~kg}$ of $\mathrm{DM} /$ ha during the experimental period.

\section{Chemical Analysis}

Composite herbage samples were analyzed in vitro for ADF (Clancy and Wilson, 1966), CP, NDF, OM digestibility (Morgan et al., 1989), and ash. During the winter period, a composite sample of grass silage was analyzed for ash, CP, NDF, and modified ADF. Concentrates were sampled weekly and bulked per month and were subsequently analyzed for ash, crude fiber, $\mathrm{CP}$, and NDF.

\section{Feed Efficiency}

Individual DMI was measured for each cow on 5 occasions during lactation (except for 10 late-calving cows, which had only 4 measurements during lactation) - from mid-March to mid-May (targeting each cow between 6 and $8 \mathrm{wk}$ of lactation), in early June, in mid-July, in early September, and in early October-providing a total of 540 records. These estimates of DMI corresponded to 51 (SD 5.8), 108 (SD 19.2), 149 (SD 20.4), 198 (SD 21.0), and 233 (SD 20.4) DIM, respectively. With the exception of the first intake measurement for each cow, in which cows were offered $2 \mathrm{~kg}$ of concentrate DM/ cow per day, cows were offered grass only. Based on the chemical analysis of the grass samples (representative of the grass consumed by the cows), the concentrations of net energy in the grass (UFL/kg of DM) were 1.06 for March, April, and May; 1.09 for June and July; 1.08 for September; and 1.01 for October, where 1 UFL is defined as the net energy content of $1 \mathrm{~kg}$ of standard barley for milk production (O'Mara, 2000). The net energy value of the concentrates offered was $1.20 \mathrm{UFL} /$ $\mathrm{kg}$ of DM.

Solids-corrected milk yield $(\mathrm{kg})$ was calculated as described by Tyrrell and Reid (1965). The measures of gross efficiency calculated were as follows: MLKS $(\mathrm{kg} / 100 \mathrm{~kg}$ of BW), SCM (kg/100 kg of BW), MLKS $(\mathrm{kg} / \mathrm{kg}$ of DMI), and total DMI (TDMI $/ 100 \mathrm{~kg}$ of BW). Energetic efficiencies examined included NEI/ MLKS, indicating the energy required to produce $1 \mathrm{~kg}$ of MLKS; (NEI - NE $\mathrm{N}_{\mathrm{M}}$ /MLKS, representing the energy required to produce $1 \mathrm{~kg}$ of MLKS after accounting for $\mathrm{NE}_{\mathrm{M}}$; and [NEI $\left.-\left(\mathrm{NE}_{\mathrm{M}}+\Delta \mathrm{NE}_{\mathrm{M}}\right) / \mathrm{MLKS}\right]$, representing the energy required to produce $1 \mathrm{~kg}$ of MLKS after adjusting the energy requirements for maintenance and BW change. Energy balance (EB) was defined as the difference between energy intake and energy required 
Table 1. Pre- and postgrazing sward surface heights, pregrazing herbage yield, and chemical composition of herbage offered

\begin{tabular}{lcc}
\hline Item & Mean & SD \\
\hline Pregrazing sward surface height $(\mathrm{cm})$ & 11.4 & 1.60 \\
Postgrazing sward surface height $(\mathrm{cm})$ & 5.1 & 0.76 \\
Pregrazing herbage yield $(\mathrm{kg}$ of $\mathrm{DM} / \mathrm{ha})$ & 1,377 & 306.6 \\
CP $(\mathrm{g} / \mathrm{kg}$ of $\mathrm{DM})$ & 199.5 & 11.55 \\
ADF $(\mathrm{g} / \mathrm{kg}$ of DM) & 218.9 & 26.62 \\
OM digestibility $(\mathrm{g} / \mathrm{kg}$ of $\mathrm{OM})$ & 809.1 & 69.7 \\
NDF $(\mathrm{g} / \mathrm{kg}$ of $\mathrm{DM})$ & 435.1 & 34.2 \\
\hline
\end{tabular}

for production, maintenance, and BW change (Faverdin et al., 2007).

Residual feed intake was estimated by regressing energy intake on its assumed components:

$$
\begin{gathered}
\mathrm{Y}=\beta 0+\beta 1(\mathrm{SCM})+\beta 2\left(\mathrm{BW}^{0.75}\right)+\beta 3(\mathrm{ADG}) \\
+\beta 4(\mathrm{BCS})+\mathrm{RFI} .
\end{gathered}
$$

The BCS nearest the week of intake measurement was included in the model based on the findings of Yan et al. (2006), who showed that BCS influenced the energy requirement for maintenance.

\section{Statistical Analysis}

The lactation was subsequently divided into 6 stages: fewer than 61 DIM, 60 to 121 DIM, 120 to 161 DIM, 160 to 191 DIM, 190 to 231 DIM, and greater than 230 DIM. The data were analyzed using the MIXED procedure of SAS (version 9.1; SAS Institute Inc., Cary, NC). The linear model included the fixed effects of breed group ( $\mathrm{HF}, \mathrm{J}$, and $\mathrm{F}_{1}$ ), parity, and lactation stage. Calving day of year was fitted as a continuous covariate. Cow was included as a random repeated effect. A compound symmetry structure for the residuals was determined using Akaike's information criterion as the most appropriate residual covariance structure for repeated measures over time within cows. Multiple comparisons were adjusted using the Bonferroni test. A contrast statement in the MIXED procedure was used to determine if significant differences existed between the $\mathrm{F}_{1}$ and the $\mathrm{HF}$ and $\mathrm{J}$ (midparent mean). Partial Pearson correlations between variables while adjusting for breed group, parity, lactation stage, and calving day of year were determined within and across breed groups using the CORR procedure of SAS.

\section{RESULTS}

\section{Feed Analysis and Sward Measurements}

Annual pasture growth was measured using $650 \mathrm{~kg}$ of nitrogen fertilizer/ha, as described by Corrall and

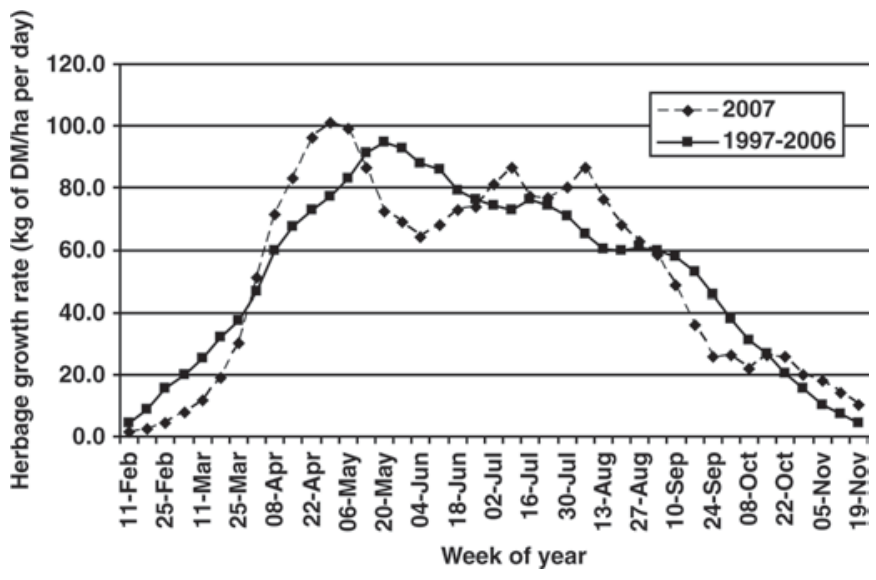

Figure 1. Daily herbage growth rates at Moorepark: 1997 to 2006 and 2007.

Fenlon (1978). This experiment was conducted nearby at Moorepark Dairy Production Research Centre (Fermoy, Co. Cork, Ireland; 50 09' N; $\left.8^{\circ} 16^{\prime} \mathrm{W}\right)$. Total grass production averaged 14.7 tonnes of $\mathrm{DM} /$ ha, compared with 15 tonnes for the average of 1997 to 2006. Hence, total grass production was typical of a normal year (Figure 1). Table 1 shows the pre- and postgrazing heights, pregrazing yield, and chemical analysis of the grass offered during the measurement periods. Table 2 shows the chemical composition of the sward deemed to have been selected by the animals.

\section{Milk Production and Composition}

The effect of dairy cow breed on mean milk production performance across the 6 stages of lactation is presented in Table 3. Breed group had a significant effect on all the production parameters investigated: yield of milk $(P<0.01)$; fat and protein yield $(P<$ 0.01 ; MLKS $)$; and milk fat $(P<0.001)$, protein $(P<$ $0.001)$, and lactose yield $(P<0.01)$. Milk yield was highest with HF $(18.3 \mathrm{~kg} / \mathrm{d})$ and lowest with $\mathrm{J}(13.8$ $\mathrm{kg} / \mathrm{d}$ ). Milk yield of $\mathrm{F}_{1}$ was intermediate, at $16.7 \mathrm{~kg} / \mathrm{d}$. Milk fat and protein contents were highest $(P<0.001)$ with $\mathrm{J}$ (5.33 and $4.06 \%$ ), intermediate with $\mathrm{F}_{1}$ (4.75 and $3.84 \%$ ), and lowest with HF (3.96 and $3.49 \%$ ). Lactose content was higher for $\mathrm{F}_{1}(4.60 \%)$ than for $\mathrm{HF}(4.49 \%)$.

Table 2. Chemical composition of herbage sampled to represent that selected by the animals

\begin{tabular}{lcc}
\hline Item & Mean & SD \\
\hline $\mathrm{CP}(\mathrm{g} / \mathrm{kg}$ of $\mathrm{DM})$ & 208.3 & 31.1 \\
$\mathrm{ADF}(\mathrm{g} / \mathrm{kg}$ of $\mathrm{DM})$ & 223.7 & 28.1 \\
$\mathrm{OM}$ digestibility $(\mathrm{g} / \mathrm{kg}$ of $\mathrm{OM})$ & 908.4 & 18.4 \\
$\mathrm{NDF}(\mathrm{g} / \mathrm{kg}$ of $\mathrm{DM})$ & 373.5 & 25.1 \\
\hline
\end{tabular}


Table 3. Effect of dairy cow breed ${ }^{1}$ on mean daily milk production performance and lactation energy requirements

\begin{tabular}{lccccc}
\hline & \multicolumn{3}{c}{ Breed group } & & \\
\cline { 2 - 4 } Trait & HF & $\mathrm{J}$ & $\mathrm{F}_{1}$ & SEM $^{2}$ & $P$-value \\
\hline Milk yield (kg) & $18.3^{\mathrm{a}}$ & $13.8^{\mathrm{b}}$ & $16.7^{\mathrm{c}}$ & 0.32 & $<0.01$ \\
Fat (\%) & $3.96^{\mathrm{a}}$ & $5.33^{\mathrm{b}}$ & $4.75^{\mathrm{c}}$ & 0.07 & $<0.001$ \\
Protein (\%) & $3.49^{\mathrm{a}}$ & $4.06^{\mathrm{b}}$ & $3.84^{\mathrm{c}}$ & 0.03 & $<0.001$ \\
Lactose (\%) & $4.49^{\mathrm{a}}$ & $4.53^{\mathrm{ab}}$ & $4.60^{\mathrm{b}}$ & 0.02 & $<0.01$ \\
Yield of milk solids (kg) & $1.33^{\mathrm{ab}}$ & $1.28^{\mathrm{a}}$ & $1.41^{\mathrm{b}}$ & 0.02 & $<0.01$ \\
SCM (kg) & $16.9^{\mathrm{a}}$ & $15.7^{\mathrm{b}}$ & $17.5^{\mathrm{a}}$ & 0.30 & $<0.05$ \\
NE $_{\mathrm{L}}\left(\mathrm{UFL}^{3}\right.$ ) & $8.11^{\mathrm{a}}$ & $7.45^{\mathrm{b}}$ & $8.32^{\mathrm{a}}$ & 0.14 & $<0.01$ \\
\hline
\end{tabular}

${ }^{\mathrm{a} c}$ Means within a row with different superscripts differ $(P<0.05)$.

${ }^{1} \mathrm{HF}=$ Holstein-Friesian; $\mathrm{J}=$ Jersey; $\mathrm{F}_{1}=$ Jersey $\times$ Holstein-Friesian.

${ }^{2} \mathrm{SEM}=$ pooled SEM.

${ }^{3}$ One UFL is defined as the net energy content of $1 \mathrm{~kg}$ of standard barley for milk production (O'Mara, 2000).

Lactose content for $\mathrm{J}(4.53 \%)$ was intermediate. Production of SCM was similar for $\mathrm{F}_{1}$ and $\mathrm{HF}$ (17.5 and $16.9 \mathrm{~kg} / \mathrm{d}$, respectively) and lowest for $\mathrm{J}(15.7 \mathrm{~kg} / \mathrm{d} ; P$ $<0.01)$. Daily MLKS production was similar for HF and $\mathrm{J}(1.33$ and $1.28 \mathrm{~kg} / \mathrm{d}$, respectively). There was a tendency, however, for $\mathrm{F}_{1}(1.41 \mathrm{~kg} / \mathrm{d})$ to produce more MLKS $(P=0.094)$ compared with HF. Corresponding $\mathrm{NE}_{\mathrm{L}}$ requirements for milk production were similar for $\mathrm{F}_{1}$ and $\mathrm{HF}$ and were lowest for $\mathrm{J}$, at 8.32, 8.11, and 7.45 UFL, respectively $(P<0.01)$. Hybrid vigor was estimated at $0.69 \mathrm{~kg} / \mathrm{d}(P=0.072), 0.09 \%(P<0.01)$, $1.25 \mathrm{~kg} / \mathrm{d}(P<0.001), 0.10 \mathrm{~kg} / \mathrm{d}(P<0.001)$, and 0.54 UFL/d $(P<0.01)$ for milk yield, milk lactose content, $\mathrm{SCM}, \mathrm{MLKS}$, and $\mathrm{NE}_{\mathrm{L}}$, respectively.

\section{$B W$ and $B C S$}

The HF breed had significantly higher BW throughout the study compared with the $\mathrm{F}_{1}$ and $\mathrm{J}$ breeds $(P<$ 0.001). Body weight was 498, 369, and $448 \mathrm{~kg}$ for HF, J, and $\mathrm{F}_{1}$, respectively (Table 4). Body weight change was similar for the 3 breed groups, corresponding to energy requirements of $1.35,0.78$, and $1.11 \mathrm{UFL}$ for $\mathrm{HF}, \mathrm{J}$, and
$\mathrm{F}_{1}$, respectively. Mean BCS was significantly higher $(P$ $<0.001)$ for $\mathrm{F}_{1}(3.00)$ and $\mathrm{J}(2.93)$ compared with HF (2.76). Hybrid vigor was estimated at $15 \mathrm{~kg}(P<0.01)$ for BW and $0.16(P<0.001)$ for BCS.

\section{TDMI and Efficiency Parameters}

Breed group had a significant effect $(P<0.001)$ on TDMI (Table 5) across the different stages of lactation $(P<0.001)$. Intake was similar for HF $(16.9 \mathrm{~kg})$ and $\mathrm{F}_{1}$ $(16.2 \mathrm{~kg})$ and was lowest for $\mathrm{J}(14.7 \mathrm{~kg})$. These intakes corresponded to NEI values of $17.8,15.6$, and $17.1 \mathrm{UFL}$ for $\mathrm{HF}, \mathrm{J}$, and $\mathrm{F}_{1}$, respectively.

Dairy cow breed had a significant effect on all the gross efficiency parameters investigated (Table 5): TDMI per $100 \mathrm{~kg}$ of BW $(P<0.01)$, SCM per $100 \mathrm{~kg}$ of BW $(P<0.01)$, MLKS per $100 \mathrm{~kg}$ of BW $(P<0.001)$, and MLKS/TDMI $(P<0.001)$. Estimated TDMI/100 $\mathrm{kg}$ of BW was highest with $\mathrm{J}(3.99 \mathrm{~kg})$, lowest with HF $(3.39 \mathrm{~kg})$, and intermediate with $\mathrm{F}_{1}(3.63 \mathrm{~kg})$. Production of SCM per $100 \mathrm{~kg}$ of BW was highest with J, intermediate with $\mathrm{F}_{1}$, and lowest with $\mathrm{HF}(4.30,3.95$, and $3.41 \mathrm{~kg}$, respectively). Similarly, the highest yield

Table 4. Effect of dairy cow breed ${ }^{1}$ on mean BW, energy required for maintenance, BW change, and BCS

\begin{tabular}{|c|c|c|c|c|c|}
\hline \multirow[b]{2}{*}{ Trait } & \multicolumn{3}{|c|}{ Breed group } & \multirow[b]{2}{*}{$\mathrm{SEM}^{2}$} & \multirow[b]{2}{*}{$P$-value } \\
\hline & $\mathrm{HF}$ & $\mathrm{J}$ & $\mathrm{F}_{1}$ & & \\
\hline $\begin{array}{l}\mathrm{BW}(\mathrm{kg}) \\
\mathrm{NE}_{\mathrm{M}}\left(\mathrm{UFL}^{3}\right) \\
\mathrm{BW} \text { change }(\mathrm{kg} / \mathrm{d}) \\
\Delta \mathrm{NE}_{\mathrm{M}}(\mathrm{UFL}) \\
\mathrm{BCS}\end{array}$ & $\begin{array}{l}498^{\mathrm{a}} \\
5.18^{\mathrm{a}} \\
0.27 \\
1.35 \\
2.76^{\mathrm{a}}\end{array}$ & $\begin{array}{l}369^{\mathrm{b}} \\
4.14^{\mathrm{b}} \\
0.14 \\
0.78 \\
2.93^{\mathrm{b}}\end{array}$ & $\begin{array}{l}448^{\mathrm{c}} \\
4.79^{\mathrm{c}} \\
0.21 \\
1.11 \\
3.00^{\mathrm{b}}\end{array}$ & $\begin{array}{l}4.68 \\
0.04 \\
0.05 \\
0.17 \\
0.03\end{array}$ & $\begin{array}{c}<0.001 \\
<0.001 \\
\text { NS } \\
\text { NS } \\
<0.001\end{array}$ \\
\hline
\end{tabular}


Table 5. Effect of dairy cow breed ${ }^{1}$ on total DMI, corresponding energy intake, and gross efficiency measures

\begin{tabular}{|c|c|c|c|c|c|}
\hline \multirow[b]{2}{*}{ Trait } & \multicolumn{3}{|c|}{ Breed group } & \multirow[b]{2}{*}{$\mathrm{SEM}^{2}$} & \multirow[b]{2}{*}{$P$-value } \\
\hline & $\mathrm{HF}$ & $\mathrm{J}$ & $\mathrm{F}_{1}$ & & \\
\hline Total DMI (kg) & $16.9^{\mathrm{a}}$ & $14.7^{\mathrm{b}}$ & $16.2^{\mathrm{a}}$ & 0.23 & $<0.001$ \\
\hline Energy intake $\left(\mathrm{UFL}^{3}\right)$ & $17.8^{\mathrm{a}}$ & $15.6^{\mathrm{b}}$ & $17.1^{\mathrm{a}}$ & 0.24 & $<0.001$ \\
\hline $\mathrm{TDMI}^{4} / 100 \mathrm{~kg}$ of BW $(\mathrm{kg})$ & $3.39^{\mathrm{a}}$ & $3.99^{\mathrm{b}}$ & $3.63^{\mathrm{c}}$ & 0.05 & $<0.01$ \\
\hline $\mathrm{SCM} / 100 \mathrm{~kg}$ of BW $(\mathrm{kg})$ & $3.41^{\mathrm{a}}$ & $4.30^{\mathrm{b}}$ & $3.95^{\mathrm{c}}$ & 0.07 & $<0.01$ \\
\hline Milk solids/100 kg of BW (kg) & $0.27^{\mathrm{a}}$ & $0.35^{\mathrm{b}}$ & $0.32^{\mathrm{c}}$ & 0.06 & $<0.001$ \\
\hline Milk solids/TDMI (kg) & $0.079^{\mathrm{a}}$ & $0.088^{\mathrm{b}}$ & $0.087^{\mathrm{b}}$ & 0.0011 & $<0.001$ \\
\hline
\end{tabular}

${ }^{\mathrm{a}-\mathrm{c}}$ Means within a row with different superscripts differ $(P<0.05)$.

${ }^{1} \mathrm{HF}=$ Holstein-Friesian; $\mathrm{J}=$ Jersey; $\mathrm{F}_{1}=$ Jersey $\times$ Holstein-Friesian.

${ }^{2} \mathrm{SEM}=$ pooled SEM.

${ }^{3}$ One UFL is defined as the net energy content of $1 \mathrm{~kg}$ of standard barley for milk production (O'Mara, 2000).

${ }^{4} \mathrm{TDMI}=$ total DMI.

of MLKS per $100 \mathrm{~kg}$ of BW was achieved by $\mathrm{J}$, at 0.35 $\mathrm{kg} / 100 \mathrm{~kg}$ of BW. The HF breed had significantly lower output of MLKS per $100 \mathrm{~kg}$ of BW compared with $\mathrm{F}_{1}$ $(P<0.001 ; 0.27$ and $0.32 \mathrm{~kg}$, respectively). Production expressed as MLKS/TDMI was more favorable for $\mathrm{J}$ and $F_{1}(0.088$ and $0.087 \mathrm{~kg} / \mathrm{kg})$ than for HF $(0.079 \mathrm{~kg} /$ $\mathrm{kg} ; P<0.001)$.

Estimates of EB were similar for $\mathrm{HF}, \mathrm{J}$, and $\mathrm{F}_{1}(4.19$, 3.72, and 3.71 UFL, respectively; Table 6). Estimated RFI was not different across the breed groups. Production efficiency expressed as NEI/MLKS was more favorable $(P<0.05)$ for $\mathrm{F}_{1}$ and $\mathrm{J}$ compared with $\mathrm{HF}$ (12.5, 13.0, and 14.1 UFL, respectively). Adjustment for maintenance $(P<0.01)$ and, subsequently, energy required for BW change $(P<0.01)$ were more favorable for $\mathrm{F}_{1}$ than for $\mathrm{HF}$, with $\mathrm{J}$ similar to both breeds. Hybrid vigor was estimated at $0.003 \mathrm{~kg} / \mathrm{kg}(P<0.05)$, $-1.05 \mathrm{UFL} / \mathrm{d}(P<0.01),-0.07 \mathrm{UFL} / \mathrm{d}(P<0.01)$, and $-0.66 \mathrm{UFL} / \mathrm{d}(P<0.05)$ for MLKS/TDMI, NEI/ MLKS, $\left(\mathrm{NEI}-\mathrm{NE}_{\mathrm{M}}\right) / \mathrm{MLKS}$, and $\left[\mathrm{NEI}-\left(\mathrm{NE}_{\mathrm{M}}+\right.\right.$ $\left.\left.\Delta \mathrm{NE}_{\mathrm{M}}\right) / \mathrm{MLKS}\right]$, respectively.

\section{Correlations}

Correlations between the various animal performance and efficiency variables across the 3 breed groups are presented in Table 7. Milk yield was positively associated with MLKS yield, SCM per $100 \mathrm{~kg}$ of BW, MLKS per $100 \mathrm{~kg}$ of BW, MLKS/TDMI, and NEI/MLKS. Moderate correlations were obtained between milk yield, BW, TDMI, and TDMI per $100 \mathrm{~kg}$ of BW. Similarly, MLKS was positively correlated with SCM per $100 \mathrm{~kg}$ of BW, MLKS per $100 \mathrm{~kg}$ of BW, and MLKS/TDMI. Weak correlations between BW and all the variables investigated were evident. Weak associations between RFI and all other variables were also observed.

\section{DISCUSSION}

The chemical analysis of the feeds and the grazing measurements are typical of a spring production system in Ireland. The chemical analysis of the herbage offered (Table 1) and assumed to have been selected (Table

Table 6. Effect of dairy cow breed ${ }^{1}$ on energy balance, residual feed intake (RFI), and net energy intake (NEI) per unit of milk solids (MLKS) production

\begin{tabular}{|c|c|c|c|c|c|}
\hline \multirow[b]{2}{*}{ Trait } & \multicolumn{3}{|c|}{ Breed group } & \multirow[b]{2}{*}{$\mathrm{SEM}^{2}$} & \multirow[b]{2}{*}{$P$-value } \\
\hline & $\mathrm{HF}$ & $\mathrm{J}$ & $\mathrm{F}_{1}$ & & \\
\hline $\begin{array}{l}\text { Energy balance }\left(\mathrm{UFL}^{3}\right) \\
\text { RFI (UFL) } \\
\text { NEI/MLKS (UFL) } \\
\left(\mathrm{NEI}-\mathrm{NE}_{\mathrm{M}}\right) / \mathrm{MLKS}(\mathrm{UFL}) \\
{\left[\mathrm{NEI}-\left(\mathrm{NE}_{\mathrm{M}}+\Delta \mathrm{NE}_{\mathrm{M}}\right) / \mathrm{MLKS}\right](\mathrm{UFL})}\end{array}$ & $\begin{array}{r}4.19 \\
-0.28 \\
14.1^{\mathrm{a}} \\
9.8^{\mathrm{a}} \\
8.7\end{array}$ & $\begin{array}{c}3.72 \\
0.10 \\
13.0^{\mathrm{b}} \\
9.3^{\mathrm{ab}} \\
8.5\end{array}$ & $\begin{array}{r}3.71 \\
-0.32 \\
12.5^{\mathrm{b}} \\
8.8^{\mathrm{b}} \\
7.9\end{array}$ & $\begin{array}{l}0.15 \\
0.17 \\
0.32 \\
0.23 \\
0.27\end{array}$ & $\begin{array}{l}\text { NS } \\
\text { NS } \\
<0.05 \\
<0.01 \\
\text { NS }\end{array}$ \\
\hline \multicolumn{6}{|c|}{$\begin{array}{l}\mathrm{a} \text { Means within a row with different superscripts differ }(P<0.05) \text {. } \\
{ }^{1} \text { Holstein-Friesian }=\mathrm{HF} \text {; Jersey }=\mathrm{J} \text {; Jersey } \times \text { Holstein-Friesian }=\mathrm{F}_{1} \text {. } \\
{ }^{2} \mathrm{SEM}=\text { pooled SEM. }\end{array}$} \\
\hline
\end{tabular}


2 ), pregrazing yield, and postgrazing sward surface heights clearly indicated that sufficient quantities of high-quality pasture were allocated to the animals over the course of the experiment (O'Donovan et al., 2004).

\section{Animal Performance Characteristics}

In the current study, differences in milk yield and milk composition (in particular, fat and protein concentrations) were apparent between HF and J. Such differences were expected based on previous studies. Mackle et al. (1996) reported higher milk yields for F, whereas milk fat and protein contents were highest with J. Oldenbroek (1988) reported milk yields of 6,432 and $3,872 \mathrm{~kg}$ for $\mathrm{H}$ and $\mathrm{J}$ cows, respectively, offered a complete diet (roughage with 50\% concentrates on a DM basis). In that study, milk fat and protein concentrations were significantly higher with J (69.1 and 42.1 $\mathrm{g} / \mathrm{kg}$ ) compared with HF (40.9 and $33.8 \mathrm{~g} / \mathrm{kg}$ ). Auldist et al. (2007) showed that $\mathrm{F}_{1}(\mathrm{~J} \times \mathrm{H})$ cows had a lower daily milk yield with higher milk contents compared with H. More recently, Heins et al. (2008) reported milk yields of 4,644 and $4,388 \mathrm{~kg}$ over the first half of lactation for $\mathrm{H}$ and $\mathrm{F}_{1}(\mathrm{~J} \times \mathrm{H})$, respectively, although 147-d fat plus protein yield was similar for both breeds (302 and $309 \mathrm{~kg}$ ). The current study indicates that hybrid vigor between the $\mathrm{J}$ and HF breeds exists for milk yield traits. This is in line with the findings of AhlbornBreier and Hohenboken (1991), who reported hybrid vigor influencing milk yield and milk fat yield. However, the authors do acknowledge the limited nature of their study with regard to drawing strong conclusions.

In the current study, BW differences were consistent with the findings of Washburn et al. (2002), who reported $\mathrm{BW}$ of 568 and $387 \mathrm{~kg}$ for lactating $\mathrm{H}$ and $\mathrm{J}$ cows at pasture. Both Heins et al. (2008) and Auldist et al. (2007) reported BW differences of 33 and $40 \mathrm{~kg}$, respectively, between $\mathrm{H}$ and $\mathrm{F}_{1}$ cows. In the present study, $\mathrm{HF}$ cows weighed $50 \mathrm{~kg}$ more than $\mathrm{F}_{1}$ and $129 \mathrm{~kg}$ more than J. Hybrid vigor was estimated at $3.2 \%$, or an additional $15 \mathrm{~kg}$. This also concurs with the findings of Lopez-Villalobos et al. (2000), who reported estimates for BW of $7.7 \mathrm{~kg}$ for $\mathrm{F}_{1}(\mathrm{~J} \times \mathrm{H})$ in New Zealand. Similarly, in the current study, the $\mathrm{J}$ and $\mathrm{F}_{1}$ cows were found to maintain higher BCS compared with the HF cows. Hybrid vigor, estimated at 0.16 units of BCS or $5 \%$, was observed. Washburn et al. (2002) also found that J cows maintained higher BCS relative to $\mathrm{H}$ cows during lactation. Auldist et al. (2007) reported that $\mathrm{F}_{1}$ cows in their study had higher BCS compared with $\mathrm{H}$ cows.

\section{Intake and Feed Efficiency}

A justification for the use of the $n$-alkane technique to predict herbage intake has been presented by Dove

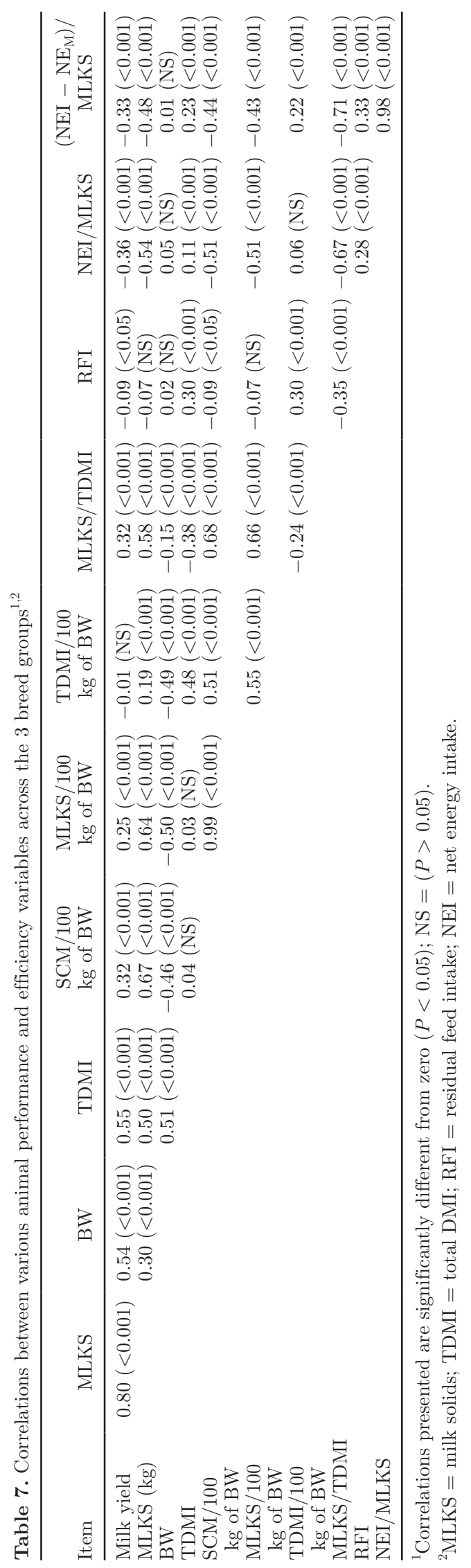


and Mayes (1991) and Berry et al. (2000). The assumption in the current study is that the technique is equally effective across breeds. A difference of $13 \%$ in TDMI was observed between $\mathrm{HF}$ and $\mathrm{J}$, with $\mathrm{F}_{1}$, on average, having a $4 \%$ lower intake (though not significant) compared with HF. This is consistent with the findings of L'Huillier et al. (1988), who reported that J cows consumed $12 \%$ less DM than F cows when allocated 20 $\mathrm{kg}$ of DM/cow per day at pasture. Mackle et al. (1996) observed an $18 \%$ difference in TDMI between HF and J cows, also under grazing conditions. More recently, a TMR study by Rastani et al. (2001) reported a difference of $26 \%$ in DMI between $\mathrm{J}$ and $\mathrm{H}$ for the first $120 \mathrm{~d}$ of lactation. Heins et al. (2008) presented data in which $\mathrm{F}_{1}(\mathrm{~J} \times \mathrm{H})$ cows had intakes similar to those of pure $\mathrm{H}$ cows (22 and $22.7 \mathrm{~kg}$, respectively). In that study, cows were individually offered a TMR diet from d 4 to 150 of lactation. González-Verdugo et al. (2005) reported similar DMI for $\mathrm{H}$ and $\mathrm{F}_{1}$ at pasture. These findings are also consistent with those of the current study, in which the DMI of $\mathrm{F}_{1}$ were similar to those of $\mathrm{HF}$ in a pasture-based environment.

Although $\mathrm{J}$ cows tend to have a reduced size (BW) and production compared with $\mathrm{HF}$, $\mathrm{J}$ cows have the ability to achieve a higher intake per unit of BW. Mackle et al. (1996) reported that $\mathrm{F}$ cows had a higher intake per day compared with J cows throughout lactation, but that $\mathrm{J}$ cows of high and low calving BW consumed 2.4 and $5.4 \%$ more DM per $100 \mathrm{~kg}$ of BW, respectively. The results from the current study concur that $\mathrm{J}$ has a higher intake capacity compared with HF. Kolver et al. (2002) reported that in grazing systems, daily feed intake is often limited to that achievable on concentrate plus conserved forage rations. Thus, although not a measure of efficiency per se, cows suited to grazing environments must be capable of achieving a high intake per unit of BW (Buckley et al., 2005). In such systems, cows must meet their energy requirements from pasture relative to their genetic potential for milk production. Berry et al. (2009) described the robustness of a dairy cow as the ability of the animal to remain close to nutritional homeostasis or to minimize the extent and duration of EB. The higher intake per unit of BW on behalf of J may be explained by the greater weights of their gastrointestinal tracts relative to HF (Smith and Baldwin, 1974). Malcolm and Grainger (2005) concluded that $\mathrm{J}$ cows consumed more DM per kilogram of BW than did $\mathrm{H}$ and $\mathrm{F}$ cows (14.4\% for the United States and $7.6 \%$ more for New Zealand). Anderson et al. (2007) reported DMI as a percentage of BW of $4 \%$ for $\mathrm{HF}$ and $4.3 \%$ for $\mathrm{F}_{1}$ and J. Heins et al. (2008) found similar DMI as a percentage of $\mathrm{BW}$ for $\mathrm{F}_{1}$ and $\mathrm{H}(4.7$ and $4.5 \%$, respectively).
High intake per unit of BW, together with low BW, facilitated higher output per unit of intake for both $\mathrm{J}$ and $F_{1}$ compared with $\mathrm{HF}$ in the present study. Grainger and Goddard (2004) showed that in 8 out of 11 studies, $\mathrm{J}$ cows had an average of $23 \%$ higher MLKS per unit of BW compared with HF cows. The current study is the first to present evidence of hybrid vigor for production per unit of BW. Buckley et al. (2007) reported a higher production of MLKS/TDMI for the HF, Montbeliarde $\times$ HF, and Norwegian Red (0.146, 0.142, and 0.149, respectively) when compared with pure Montbeliarde and Normande (0.132 and 0.125, respectively).

Veerkamp et al. (1995) argued that gross efficiency is a ratio of 2 quantities, implying that cows with a low MLKS output or a high DMI may have low FCE. Furthermore, gross efficiencies do not apportion the energy requirements to the separate functions (maintenance, lactation, body tissue gain, pregnancy, etc.). Berry (2009) pointed to disadvantages with ratio measures from the perspective of selection procedures. Residual feed intake accounts for maintenance, metabolic BW, $\mathrm{ADG}$, and SCM for the animal relative to the population or group mean. Although RFI is viewed as a very suitable or appropriate trait to characterize feed efficiency with beef cattle, from a dairy perspective it poses enormous difficulty. For example, dairy cows mobilize body reserves in early lactation (Buckley et al., 2003) and replenish these reserves to varying degrees in late lactation or in the dry period. Large data sets would appear to be required to observe statistically relevant differences between strains or breeds. Furthermore, highly efficient dairy cows from an RFI perspective, in fact, may not be the most efficient from a production efficiency (input per saleable output) and, consequently, a profit perspective unless restricted to high-yielding cows. Nor might they be most suited to a seasonal grass-based system (Buckley et al., 2005, 2007). In any case, no difference in RFI was observed in the current study despite the diverse nature of the breed groups under investigation. The large standard error observed for RFI may simply imply that a data set larger than the one available in the current study is required to truly determine whether differences in RFI exist between the breed groups investigated.

From a practical perspective, a key determinant of production efficiency must be NEI per unit of MLKS produced (or indeed per unit of milk volume where fluid milk is the preferred output) or, broadly reversed, MLKS output per unit of intake. Results from the current study suggest that $\mathrm{J}$ and $\mathrm{F}_{1}(\mathrm{~J} \times \mathrm{HF})$ cows require approximately 8 and $11 \%$ less energy, respectively, to produce $1 \mathrm{~kg}$ of MLKS compared with HF cows. Schwager-Suter et al. (2001) also investigated differences in 
net energetic efficiency for $\mathrm{H}, \mathrm{J}$, and $\mathrm{F}_{1}(\mathrm{~J} \times \mathrm{H})$ cows. In that study, net energy efficiency was calculated as the ratio of milk energy to total NEI after subtracting energy utilized for maintenance and body tissue change. Results from that study indicated that $\mathrm{F}_{1}(\mathrm{~J} \times \mathrm{H})$ cows had a higher ECM-to-NEI ratio compared with those of the HF and J breeds. Furthermore, in the current study, evidence of hybrid vigor is presented for NEI per unit of MLKS (even when adjusted for $\mathrm{NE}_{\mathrm{M}}$ and $\Delta \mathrm{NE}_{\mathrm{M}}$ ), resulting in at least parity with the pure $\mathrm{J}$ cows.

To improve feeding system efficiency, a sound understanding of the concepts and errors associated with FCE are important (Beever and Doyle, 2007). A robust uniform approach would be most desirable. Practically, it is difficult to gather information on feed efficiency. Therefore, variables that can be correlated with feed efficiency and easily measured may be used to select indirectly for feed efficiency. Buckley et al. (2007) reported that the greatest efficiency in terms of MLKS per 100 $\mathrm{kg}$ of $\mathrm{BW}$ was achieved by HF, Montbeliarde $\times \mathrm{HF}$, and Norwegian Red, at $0.43,0.41$, and 0.42 (high-producing cows), respectively, compared with Montbeliarde, Normande, and Normande $\times \mathrm{HF}$, at $0.37,0.33$, and 0.39 , respectively. This seems to comply with the hypothesis that high-yielding animals or breeds are more efficient (McNaughton and Pryce, 2008), suggesting that selection for high MLKS yield (more especially when a negative weighting is placed on milk volume, BW, or both); for example, in the New Zealand selection index, breeding worth will increase feed efficiency. The correlations measured throughout lactation in the current study indicate that increased MLKS yield is associated with higher gross efficiency measures, but also favorable production efficiency measures (NEI/MLKS and NEI - $\mathrm{NE}_{\mathrm{M}} / \mathrm{MLKS}$ ). However, correlations between MLKS and gross efficiency measures are likely to be affected by part-whole relationships (Berry, 2009). No clear relationship is apparent between BW per se and any of the measures investigated, indicating that across the current data set, efficiency was independent of animal size. In contrast, Dickinson et al. (1969) found negative correlations between feed efficiency (energy in milk/ energy in feed) and BW in first-lactation animals.

\section{CONCLUSIONS}

Dairy systems in which pasture environments are core to production are dependent on cows achieving high DMI per unit of BW, with high MLKS production per unit of intake. The results from this study indicate that differences in animal production performance characteristics - milk yield and milk composition, BW, BCS, and TDMI - exist between the HF and $\mathrm{J}$ breeds. The reputed superior intake per unit of BW and gross production efficiency characteristics of $\mathrm{J}$ were also confirmed in this study. The results also indicate that crossing HF with $\mathrm{J}$ will result in cows very suited to grazing systems, as evidenced by the high intake capacity at pasture, with the added benefit of improved production and feed efficiency. This is borne out of additive genetic improvement caused by the superiority of the $\mathrm{J}$ breed compared with the HF breed in this regard, but is also contributed to by hybrid vigor and the complementarity of the 2 breeds.

\section{ACKNOWLEDGMENTS}

The authors acknowledge the financial support of the Research Stimulus Fund (RSF-06-353). The technical assistance of Flor Flynn, Norann Galvin, and Christine Fleming (Teagasc, Moorepark, Ireland) and the diligent work of Noel Byrne and the farm staff at the Ballydague Research Farm (Ireland) is gratefully acknowledged.

\section{REFERENCES}

Ahlborn-Breier, G., and W. D. Hohenboken. 1991. Additive and nonadditive genetic effects on milk production in dairy cattle: Evidence for major individual heterosis. J. Dairy Sci. 74:592602.

Anderson, T., R. Shaver, P. Bosma, and V. DeBoer. 2007. Case study: Performance of lactating Jersey and Jersey-Holstein crossbred versus Holstein cows in a Wisconsin confinement dairy herd. Prof. Anim. Sci. 23:541-545.

Auldist, M. J., M. F. S. Pyman, C. Grainger, and K. L. MacMillan. 2007. Comparative reproductive performance and early lactation productivity of Jersey $\times$ Holstein cows in predominantly Holstein herds in a pasture-based dairy system. J. Dairy Sci. 90:48564862 .

Beever, D. E., and P. T. Doyle. 2007. Feed conversion efficiency as a key determinant of dairy herd performance: A review. Aust. J. of Exp. Agric. 47:645-657.

Berry, D. P. 2009. Improving feed efficiency in cattle with residual feed intake. Pages 67-99 in Recent Advances in Animal Nutrition. Nottingham University Press, Nottingham, UK.

Berry, D. P., B. Horan, M. O'Donovan, F. Buckley, E. Kennedy, M. McEvoy, and P. Dillon. 2007. Genetics of grass dry matter intake, energy balance, and digestibility in grazing Irish dairy cows. J. Dairy Sci. 90:4835-4845.

Berry, D. P., M. O'Donovan, and P. Dillon. 2009. Potential to genetically alter intake and energy balance in grass fed dairy cows. Pages 219-224 in Breeding for Robustness in Cattle. EAAP Publ. No. 126. Wageningen Academic Publishers, Wageningen, the Netherlands.

Berry, N. R., M. R. L. Scheeder, F. Sutter, T. F. Kröber, and M. Kreuzer. 2000. The accuracy of intake estimation based on the use of alkane controlled-release capsules and faeces grab sampling in cows. Ann. Zootech. 49:3-13.

Buckley, F., P. Dillon, P. Crosse, F. Flynn, and M. Rath. 2000. The performance of Holstein-Friesian dairy cows on high and medium genetic merit for milk production on grass based systems. Livest. Prod. Sci. 64:107-119.

Buckley, F., C. Holmes, and M. G. Keane. 2005. Genetic characteristics required in dairy and beef cattle for temperate grazing systems. Pages 61-79 in Utilization of Grazed Grass in Temperate Animal Systems. Proc. Satellite Workshop XXth Int. Grassl. Congr., Cork, Ireland.

Buckley, F., B. Horan, N. Lopez-Villalobos, and P. Dillon. 2007. Milk production efficiency of varying dairy cow genotypes under razing conditions. Pages $74-83$ in Meeting the Challenges for Pasture-Based Dairying. Proc. 3rd Dairy Sci. Symp., University of Melbourne, Victoria, Australia. 
Buckley, F., K. O'Sullivan, J. F. Mee, R. D. Evans, and P. Dillon. 2003. Relationships among milk yield, body condition, cow weight, and reproduction in spring-calved Holstein-Friesians. J. Dairy Sci. $86: 2308-2319$

Clancy, M. J., and R. K. Wilson. 1966. Development and application of a new chemical method for predicting the digestibility and intake of herbage samples. Pages 445-452 in Proc. 10th Int. Grassl. Congr., Helsinki, Finland. Valtioneuvoston Kirjapaino, Helsinki, Finland.

Corrall, A. J., and J. S. Fenlon. 1978. A comparative method for describing the seasonal distribution of production from grasses. J. Agric. Sci. 91:61-67.

Dickinson, F. N., B. T. McDaniel, and R. E. McDowell. 1969. Comparative efficiency of feed utilization during first lactation of Ayrshire, Brown Swiss, and Holstein cows. J. Dairy Sci. 52:489497.

Dillon, P. 1993. The use of $n$-alkanes as markers to determine intake, botanical composition of available or consumed herbage in studies of digesta kinetics with dairy cows. PhD Thesis. National University of Ireland, Dublin.

Dillon, P., S. Crosse, G. Stakelum, and F. Flynn. 1995. The effect of calving date and stocking rate on performance of spring calving dairy cows. Grass Forage Sci. 50:286-299.

Dove, H., and R. W. Mayes. 1991. The use of plant wax alkanes as marker substances in studies of the nutrition of herbivores: A review. Aust. J. Agric. Res. 42:913-952.

Faverdin, P., R. Delagarde, L. Delaby, and F. Meschy. 2007. Alimentation des vaches laitières. Pages $23-55$ in Alimentation des bovins, ovins et caprins. QUAE Editions, INRA, Versailles, France.

González-Verdugo, H., J. C. Magofke, and C. Mella. 2005. Productivity, intake and biological efficiency in New Zealand Friesian and $F_{1}$ (Jersey-New Zealand Friesian) cows calved during late winter in the Xth Region, Chile. Arch. Med. Vet. 37:37-47.

Grainger, C., and M. E. Goddard. 2004. A review of the effects of dairy breed on feed conversion efficiency-An opportunity lost? Pages 77-80 in Animal Production in Australia: Proc. 25th Biennial Conf. Aust. Soc. Anim. Prod., University of Melbourne, Victoria. Commonw. Sci. Ind. Res. Org., Victoria, Australia.

Hansen, L. B. 2006. Monitoring the worldwide genetic supply for dairy cattle with emphasis on managing crossbreeding and inbreeding. 8th World Congr. Genet. Appl. Livest. Prod., Belo Horizonte, Minas Gerais, Brazil.

Heins, B. J., L. B. Hansen, A. J. Seykora, A. R. Hazel, D. G. Johnson, and J. G. Linn. 2008. Crossbreds of Jersey $\times$ Holstein compared with pure Holsteins for body weight, body condition score, dry matter intake, and feed efficiency during the first one hundred fifty days of first lactation. J. Dairy Sci. 91:3716-3722.

Kennedy, E., M. O'Donovan, F. P. O'Mara, J. P. Murphy, and L. Delaby. 2007. The effect of early-lactation feeding strategy on the lactation performance of spring-calving dairy cows. J. Dairy Sci. 90:3060-3070.

Koch, R. M., L. A. Swiger, D. Chambers, and K. E. Gregory. 1963. Efficiency of feed use in beef cattle. J. Anim. Sci. 22:486-494.

Kolver, E. S., J. R. Roche, M. J. de Veth, P. L. Thorne, and A. R. Napper. 2002. Total mixed rations versus pasture diets: Evidence for a genotype $\times$ diet interaction in dairy cow performance. Proc. N. Z. Soc. Anim. Prod. 62:246-251.

L'Huillier, P. J., C. R. Parr, and A. M. Bryant. 1988. Comparative performance and energy metabolism of Jerseys and Friesians in early lactation. Proc. N. Z. Soc. Anim. Prod. 48:231-235.

Lopez-Villalobos, N., D. P. Berry, B. Horan, F. Buckley, J. Kennedy, M. O'Donovan, L. Shalloo, and P. Dillon. 2008. Genetics of residual feed intake in Irish grazing dairy cows. Proc. N. Z. Soc. Anim. Prod. 68:97-100.

Lopez-Villalobos, N., D. J. Garrick, C. W. Holmes, H. T. Blair, and R. J. Spelman. 2000. Profitabilities of some mating systems for dairy herds in New Zealand. J. Dairy Sci. 83:144-153.

Lowman, B. G., N. Scott, and S. Somerville. 1976. Condition scoring of cattle. In Bull. East Scotland Coll. Agric. No. 6. Rev. ed. East of Scotland College of Agriculture, Edinburgh, UK.
Mackle, T. R., C. R. Parr, G. K. Stakelum, A. M. Bryant, and K. L. Macmillan. 1996. Feed conversion efficiency, daily pasture intake, and milk production of primiparous Friesian and Jersey cows calved at two different liveweights. N. Z. J. Agric. Res. 39:357-370.

Malcolm, B., and C. Grainger. 2005. Implications of changing a Friesian dairy system to a Friesian-Jersey crossbred system. Ext. Farming Syst. J. 1:37-44.

Mayes, R. W., C. S. Lamb, and P. M. Colgrove. 1986. The use of dosed and herbage n-alkanes as markers for the determination of herbage intake. J. Agric. Sci. (Camb.) 107:161-170.

McNaughton, L. R., and J. E. Pryce. 2008. Metabolic feed efficiencyOpportunities for selection in dairy cows. Proc. N. Z. Soc. Anim. Prod. 67:392-398.

Miglior, F., B. L. Muir, and B. J. Van Doormaal. 2005. Selection indices in Holstein cattle of various countries. J. Dairy Sci. $88: 1255-1263$.

Morgan, D. J., G. Stakelum, and J. Dwyer. 1989. Modified neutral detergent cellulase digestibility procedure for use with the "fibretec" system. Isr. J. Agric. Res. 28:91-92.

Ngwerume, F., and I. L. Mao. 1992. Estimation of residual energy intake for lactating cows using animal model. J. Dairy Sci. $75: 2283-2287$

O'Donovan, M., J. Connolly, P. Dillon, M. Rath, and G. Stakelum. 2002. Visual assessment of herbage mass. Ir. J. Agric. Food Res. $41: 201-211$

O'Donovan, M., L. Delaby, and J. L. Peyraud. 2004. Effect of time of initial grazing date and subsequent stocking rate on pasture production and dairy cow performance. Anim. Res. 53:489-502.

Oldenbroek, J. K. 1988. The performance of Jersey cows and cows of larger dairy breeds on two complete diets with different roughage contents. Livest. Prod. Sci. 18:1-17.

O'Mara, F. 2000. A Net Energy System for Cattle and Sheep. Version 1.2. Univ. Coll. Dublin, Ireland.

Rastani, R. R., S. M. Andrew, S. A. Zinn, and C. J. Sniffen. 2001. Body composition and estimated tissue energy balance in Jersey and Holstein cows during early lactation. J. Dairy Sci. 84:12011209.

Schwager-Suter, R., C. Stricker, D. Erdin, and N. Kunzi. 2001. Net efficiencies of Holstein, Jersey and $\mathrm{F}_{1}$-crosses. Anim. Sci. 72:335342 .

Shalloo, L. 2007. Increasing milk value. Taking costly water out of milk. Pages 83-96 in Proc. Ir. Grassl. Assoc. Dairy Conf., Co. Cork, Ireland, Jan. 25, 2007. Ballybrit Industrial Estate,

Shalloo, L., P. Dillon, M. Rath, and M. Wallace. 2004. Description and validation of the Moorepark Dairy System model. J. Dairy Sci. 87:1945-1959.

Smith, N. E., and R. L. Baldwin. 1974. Effects of breed, pregnancy and lactation on weight of organs and tissues in dairy cattle. J. Dairy Sci. 57:1055-1060.

Tyrrell, H. F., and J. T. Reid. 1965. Prediction of the energy value of cow's milk. J. Dairy Sci. 48:1215-1223.

Urban, B., and J. P. Caudal. 1990. Herbometre automatise (Automatic platemeter). Pages 57-59 in Les Journées de la Mesure: Électronique, Informatique, Automatique. Port Leucate, France. Institut National de la Recherche Agronomique, Paris, France.

Veerkamp, R. F., G. C. Emmans, A. R. Cromie, and G. Simm. 1995. Variance components of residual feed intake in dairy cows. Livest. Prod. Sci. 41:110-120.

Walsh, S., F. Buckley, D. P. Berry, M. Rath, K. Pierce, N. Byrne, and P. Dillon. 2007. Effects of breed, feeding system, and parity on udder health and milking characteristics. J. Dairy Sci. 90:57675779 .

Washburn, S. P., S. L. White, J. T. Green Jr., and G. A. Benson. 2002. Reproduction, mastitis, and body condition of seasonally calved Holstein and Jersey cows in confinement or pasture systems. J. Dairy Sci. 85:105-111.

Yan, T., C. S. Mayne, T. W. J. Keady, and R. E. Agnew. 2006. Effects of dairy cow genotype with two planes of nutrition on energy partitioning between milk and body tissue. J. Dairy Sci. 89:10311042. 